\title{
The Internal Security Package and Its Potential Impact on the EU-Turkey Relations within the Scope of Fundamental Rights and Freedoms
}

\author{
Vahap Atilla Oğuşgil \\ Department of Political Science and Public Administration, \\ Faculty of Economics and Administrative Sciences, \\ İnönü University \\ Malatya, Turkey \\ E-mail: atillaogusgil@gmail.com
}

Abstract: Being one of the core values of the European Union, human rights have been centrally located in the European Union-Turkey relations especially since the country gained the candidate status in 1999. In human rights practices, the actor who comes to the forefront most on behalf of the state against the citizens whose rights must be protected is the police force. Therefore, the security practices enforced by the police form a huge part of human rights practices in the state and thus play a decisive role in Turkey's relations with the Union. This article presents an evaluation of the so-called 'internal security package', which has just passed into law, and its potential impact on European Union-Turkey relations. The package includes specific amendments regarding the police duties and authorities, which unarguably affect human rights practices in the country. As the Union lacks a uniform norm relating to the security practices the package in question contains, the answer to the question will be sought by screening two sources: EU progress reports on Turkey and relevant ECtHR decisions, which provide definite judgements regarding the threats and risks posed by the package under discussion.

Keywords: European Union, fundamental rights and freedoms, internal security package, police duties and authorities, Turkey 


\section{Introduction}

Turkey, which has been endeavouring to be a member of the European Union (EU) for over 50 years, eventually gained the status of candidate country at the 1999 Helsinki Summit and, in order to be able to start the accession negotiations, undertook the responsibility of the formation of stable institutions guaranteeing democracy, the rule of law, human rights and minority rights pursuant to Copenhagen political criteria. Out of the 15 chapters opened since 2005, when the negotiations with the Union for full membership started, only one could be temporarily closed. The EU notes certain problems regarding most of the chapters composed of 35 titles in total and regulated for the country's harmonization to Union legislation and considers it necessary to make significant efforts for the solution of these problems. One of the issues that the Union regards problematic, often criticizes and points out vigorous efforts to be made in this direction concerns fundamental rights and freedoms.

The EU's consideration of democracy, the rule of law and respect for human rights as both the building blocks of the Union and the primary condition for the candidate countries pursuing membership makes the issue in question more meaningful for Turkey in its accession negotiations process. Because, the issue of human rights is among the most problematic issues in Turkey's relations with the Union both prior to and after candidacy. For this reason, human rights, which takes place among the Copenhagen political criteria and plays a decisive role in EU-Turkey relations, is one of the leading issues on which Turkey must put particular emphasis. In this sense, the creation of stable institutions guaranteeing the protection of human rights is of paramount importance for Turkey aiming membership.

One of the institutions that must be created or structured within the framework in question is the police organization. This is the institution that comes to mind first in the case of any practices that lead to human rights violations. It is necessary to express that in accordance with the responsibilities undertaken, right after gaining the status of candidate country, Turkey made many reforms which directly influence security practices and ensure the fundamental rights and freedoms of the individuals against the police practices.

On the other hand, considering the fact that a significant part of the human rights violations detected by European Court of Human Rights (ECtHR) has originated from police practices in Turkey and this has been reflected in the EU's progress reports on Turkey, as well, it is also necessary to add that there 
are many more steps to be taken, because this negative picture directly affects Turkey's relations with the EU and leaves the country in a difficult situation. As a result, police practices comprise a considerable part of human rights practices in Turkey and play a leading role in the course of Turkey's relations with the EU within the context of fundamental rights and freedoms. If Turkey does not want to have a trouble with the EU within the aforesaid context, it must be careful with respect to tasks and authorities entrusted to the police and act responsibly in establishing the freedom-security balance.

This study investigates the probable impact of the legislative arrangement just made pursuant to what is known as 'internal security package' in relation to police duties and authorities on EU-Turkey relations within the context of fundamental rights and freedoms. Since there is no direct and uniform EU norm concerning the arrangements prescribed by the package, the investigation at issue will be made based on the related ECtHR decisions and EU progress reports on Turkey, which present explicit judgements in relation to the alarming matters posed by the package under discussion.

\section{Europeanization of Turkey after the 1999 Helsinki Summit}

The 1999 Helsinki Summit opened a new era in EU-Turkey relations, since reforms on human rights gathered momentum in order to start the negotiations. The summit provided a turning point in the long-standing EU-Turkey relations by bringing into attention the political criteria for membership, which had been an ignored and missing element in the process of Europeanization in Turkey (Eralp \& Torun, 2015, p. 26). As a natural consequence of this development, Turkey has adopted many political reforms and legal changes to satisfy the Copenhagen criteria and thus pave the way for the consolidation of the Europeanization process. The country progressed notably in the consolidation of democracy, the rule of law and human rights within the scope of alignment with the EU acquis (Özdemir \& Demirkanoğlu, 2014, p. 122). Two main instruments were used in the actualization of this reform process: amendment of the constitution and harmonization packages.

The 2001, 2004 and 2010 constitutional amendments, for example, brought clear innovations in EU standards regarding the freedom of thought and expression, the prevention of torture, the freedom of association, the freedom of press, the freedom of movement, gender equality, children's rights, strengthening of civilian authority and democracy, making international treaties concerning 
fundamental rights and freedoms gain precedence over national legislation, the freedom and security of the individual, the right to petition to an ombudsman, the right to privacy, abolishment of death penalty, abolishment of State Security Courts, positive discrimination concerning members of certain disadvantaged social groups that require special protection, the right to submit constitutional complaints and so on. ${ }^{1}$

In addition to those amendments made in the constitution, Turkey witnessed nine harmonization packages between the years 2002 and 2006, which were prepared to bring Turkish legislation in line with the EU legislation. These packages made specific changes in a large number of laws such as: Penal Code, the Antiterror Law, the Code of Criminal Procedure, the Press Law, the Law on Political Parties, the Law on Associations, the Law on Meetings and Demonstration Marches, the Law on Foreign Language Teaching and Education, and the Law on the Duties and Competences of the Police. The packages in general were adopted to improve human rights, including the minority rights, broaden freedom of expression and freedom of press, strengthen safeguards against torture and mistreatment, intensify the freedom of association, assembly and demonstration, expand cultural rights, guarantee broadcasting and education in other languages, support gender equality and consolidate democracy (Ministry of Foreign Affairs, 2007, p. 18).

All in all, these reforms, generated as a result of Turkey's enthusiasm for Europeanization, played a significant role in strengthening and deepening democratic norms and values in the Turkish political system (Özbudun, 2004, p. 179), and eventually urged the EU to start accession negotiations with the country for full membership on October 3rd, 2005.

With regard to Europeanization, much of the related literature on EU-Turkey relations regards the period between 2001 and 2006 rather successfully and notably (Grigoradis, 2009, p. 155; Öniş, 2010, p. 363; Hale, 2011, p. 325). This pre-negotiations period is even characterized as 'the golden age of Europeanization' (Öniş, 2008, p. 40). The period after 2006, however, marks a different era in terms of reforms and Europeanization. In this period, the democratic reforms lost momentum, then came to a halt and eventually went into reverse gear. Thus, this post-negotiations period represents a U-turn from the so-called golden age of Europeanization (Saatçioğlu, 2013, p. 18).

For a detailed analysis of the 2001, 2004 and 2010 constitutional amendments, see Coşkun, 2013. 
The stopping of reforms can be attributed to all actors active in the process: EU, Member States and Turkey. In the first place, the negotiations' being openended, suspension of membership negotiations over five acquis chapters due to France's veto and six acquis chapters due to Cyprus' veto and ongoing doubts of Austria, Germany and France about Turkey's membership and even Merkel's "privileged partnership" proposal for Turkey led to a decline in enthuasism in Turkey. Those obstacles raised by the EU and some Member States on the road to membership adversely affected the Government's eagerness and faith in the membership process.

The other reason that distanced Turkey from democratic reforms is connected with Turkey itself. The second (2007) and the third (2011) terms of the ruling party, Justice and Development Party (AKP), had to deal with critical domestic affairs including high tension and polarization in the society such as the election of the new president that turned into a political crisis, e-memorandum issued by the military, closure case prosecuted against it on charges of becoming the focus of anti-secularist activity, rising terrorist attacks of the Kurdistan Workers' Party (PKK) on civilian and military targets, Kurdish issue, the trial of 'Ergenekon', and lastly 'parallel state', which were both considered by the Government as illegal organizations consisting of persons from the bureaucracy, military, universities, intellectuals, media and planning to overthrow the Government. In brief, certain domestic factors, which have a determining role in AKP's political references based on strategic calculations, have shaped the Europeanization outcomes in the reform areas in those periods (Saatçioğlu, 2014, p. 87; Y1lmaz \& Soyaltın, 2014, p. 12).

The Government spent much of its effort and time in those terms to fight against the aforementioned powers. The power struggle of the Government against those power elites forced it to take strategic steps that would strengthen its power over especially judiciary, military and media. This struggle then led the Government to engage in legislative efforts which aimed to empower its rule within the state and give explicit priority to security over freedoms. As a consequence, those initiatives yielded many laws inconsistent with the European standards including, for instance, the Law on the National Intelligence Services and Internet Law, which, according to the EU, "allows wiretappings and surveillance to be conducted by Turkish intelligence services without judicial oversight" and which "increases the Government's powers to block content without Court order on an unduly wide range of grounds" (EC, 2014, p. 14 and EC, 2015, p. 5), respectively. The EU, as a result, regarded the adoption of those laws as a setback from European standards. 
In conclusion, the post-2007 period could be characterized as the 'AKP's power consolidation' (Saatçioğlu, 2014, p. 93) period in which the Government started to rule with an exaggerated sense of its own power (Öniş, 2010, p. 370). In this post-negotiations period, rather than EU conditionality, domestic political calculations were the major impetus for political reforms. In this period, the Government adopted a 'pick-and-choose' (Saatçioğlu, 2014, p. 87) type of Europeanization, which signifies a selective Europeanization process including several setbacks especially in freedom of speech, freedom of media and independence of judiciary. This situation, which is a clear indication of reversal from Europeanization, also casts a shadow over pluralizm (Kaliber, 2014, p. 41), which is usually used synonymously with Europeanization (Alpan \& Diez, 2012).

\section{Internal security package}

The motivation behind the adoption of the package in question is based on the protest demonstrations held in various cities of Turkey on 6-8 October 2014 in reaction to assaults of the terrorist organization known as the 'Islamic State of Iraq and the Levant' (ISIL, known as ISID in Turkey) to the Syrian town of Kobani. Turkey witnessed a turbulent period in especially October 2014 both in the society in general and political sphere. This was the period of political tension especially between the ruling party AKP and People's Democratic Party (HDP), which mainly represents Kurdish population in Turkey, due to the siege of Kobani by ISIL. This political and societal turbulence resulted in violent demonstrations including 50 deaths and more injured.

As is known, ISIL is an illegal armed organization, which is predominantly active in Iraq and Syria. The organization, which drew the attention of the entire world especially after the occupation of Mosul in Iraq in June 2014, has displayed the same expansionist policies in Syria, as well. The assaults of ISIL in different parts of Syria does not attract considerable attention by the Turkish public opinion until it arrives at the town of Kobani. When ISIL started to assault Kobani in July 2014, this situation created great reactions in Turkey both among the political circle and the public. Encircling of the town, which is considered the heart of the Kurdish area in North Syria, instigated the Kurdish society the most in Turkey. Initially, certain non-governmental organizations and the HDP protested the siege. They also accused Turkish Government of remaining passive against the assaults for Kobani and asked for the Government to open a 
corridor for Kurdish fighters to cross into the besieged town. As time passed by and the assaults of ISIL intensified, the reactions of the Kurdish population in Turkey turned into demonstrations including violence and assaults. As a result, between 6 and 8 October 2014, fifty people died in the escalated protests.

Following this deplorable event, the Turkish Government decided to draft a law with the aim of preventing those violent demonstrations which caused serious loss of life and property. The package, which was submitted to the Turkish Parliament at the end of 2014, caused great controversy and conflict both in the public opinion and the Grand National Assembly of Turkey (TBMM). In contrast to the Government, which asserts that the package was prepared by taking the security practices in Germany as a model and is compatible with the European standards, the opposition parties in particular and the public opinion in general objected the package claiming that it includes provisions conflicting with democracy and international human rights standards.

In addition, the prevalent opinion both in the eyes of politicians in the opposition parties and the public opinion in general was that the package was prepared very hastily without consultation with the other political groups in the Parliament, civil society and other stakeholders and thus ignoring the pluralist nature of the Parliament and the society, as well. The package was even considered a very harsh method of dealing with terrorism, as it extends police powers and situations to conduct searches, use their weapons and detain suspects in custody without a warrant (Zeldin, 2015, p. 4). The package, which was ultimately passed into law on 27 March 2015, ${ }^{2}$ made significant amendments regarding the legislation for particular police duties and authorities such as; 'detention', 'intervention in social incidents' and 'search', each of which touches specific human rights of the citizens.

The package is significant for Turkey itself since it contains many provisions touching upon democracy and human rights, two indispensable conditions for democratic states. It will inarguably create certain impacts on the development of democracy as well as protection and promotion of human rights in Turkey. The package is also significant for EU-Turkey relations as those conditions are directly relevant with the Copenhagen political criteria, necessary to start the negotiations. Among the negotiating chapters, the package is relevant with Chapter 23, 'Judiciary and Fundamental Rights', and Chapter 24, 'Justice, Freedom and Security', which include the hugest amount of criticism on Turkey

2 The Law no. 6638 Amending the Law on Police Duties and Authorities, Law on Gendermerie Organization, Duties and Authorities and Certain Laws' (henceforth, Law no. 6638). 
by the EU. All these make the package at issue worthy of discussing with respect to the course of EU-Turkey relations in the future.

\section{Security duties and human rights}

Human rights arise from the relationship between the individuals and state. Both implementation and violation of those rights are closely related to the organization and acts of the state (Cavalieri, 2005, p. 38). Also, human rights could be considered as a benchmark for legitimacy of a state (Hafner-Burton, Tsutsui \& Meyer, 2008, p. 116). The benchmark in question prevails not only with respect to the individual-state relations at the national level but also the states' commitment to international law in international relations (Güven, 2006, p. 79). Within this context, in order not to jeopardize their legitimacy modern states expend energy on protecting and promoting rights of the individuals through their bodies and facilities.

Regarding their duties and authorities and dealing with people's actions as part of their profession, the body representing the state against the individuals is mostly the police organization. The police is one of the state's most important and powerful institution, which directly reaches the public. It is also a visible manifestation of public power and a state organ which intensely keeps in touch and contact with civil society (Bowling et al., 2004, p. 1). In this sense, the practices of the state's most visible actor in question is a factor that directly influences the human rights record of the states.

In the most general sense, the police is charged with ensuring public order and safety. During the execution of his task in question, he touches many fundamental rights and freedoms of the individuals through his intervention. In this sense, there appears a direct and close relationship between the security duties performed by the police and human rights (Karaosmanoğlu, 2012, p. 43). The security duties, for instance, have an effect on various fundamental rights such as: the right to life, right to liberty and security, freedom of expression, freedom of peaceful assembly and right to respect for private and family life (Crawshaw, 1997, p. 11). To put it more explicitly, its authority to use firearm, detain and search either secures or violates the right to life, the right to liberty and security and the right of privacy, respectively.

That the police is obliged to ensure public order and safety on the one hand and fundamental rights and freedoms of the individuals on the other hand is, in fact, a 
paradox. While taking measures for ensuring public safety, the police is required to protect the fundamental rights and freedoms of the individuals. The necessity of establishing freedom-security balance sensitively is also considered important by the EU. The EU Network of Independent Experts on Fundamental Rights, for example, emphasizes that the effectiveness of measures taken to maintain security cannot be measured by the extent of the restrictions that these measures impose on fundamental rights and freedoms. In addition, the measures are to be limited to what is absolutely necessary and avoid a risk of arbitrariness (EU Network of Independent Experts on Fundamental Rights, 2003, pp. 10, 52). Therefore, like all other states, Turkey, while investing the police with the required authorities, must pay regard to this delicate balance. Otherwise, any disorder in the freedom-security balance against freedom will make new human rights violations unavoidable. This situation will then adversely affect the relations of Turkey, which has been currenty conducting negotiation process, with the EU.

\subsection{Detention}

Detention is a primary authority within the jurisdiction of the police. Detention, which shortly indicates 'the state of the person captured' (Yenisey, 1995, p. 114), is one of the protection measures intended to ensure that criminal procedure is carried out, to make a decision suitable for the subject of the conflict at the end of the procedure and to be able to execute the decision made (Centel, 1994, p. 70). The right to liberty and security and the right to life or prohibition of torture and inhuman or degrading treatment are considered among the fundamental rights which are affected most during detention.

One of the most striking features of the Law no. 6638 that this study addresses is that it grants the police the authority to detain. Such authority, previously given only to the public prosecutor, has now been vested in the police through the governor that represents an administrative authority. In accordance with the amendment made by the subject law in Article 91 of the Law of Criminal Procedure no. 5271 the police has been granted the authority to detain up to 24 hours in case of personal crimes and 48 hours in case of collective crimes upon the order of their superior to be appointed by the local authority without the need for the decision of the prosecutor in case of catching red-handed. In addition, the police shall report to the public prosecutor on the procedure followed in relation to the person caught red-handed at the end of such 48 hours and act upon the instruction given by the prosecutor (Law no. 6638, Art. 13).

The practices which will be carried into effect in accordance with such amendment that gives the police the right to detain for 48 hours and that engages 
the prosecutor only at the end of this time suggest an alarming condition with regard to the right to liberty and security, in particular, and the right to life or prohibition of torture and inhuman or degrading treatment. This is because whereas the limitations to the fundamental rights and freedoms which also include the right to liberty and security must prioritize the decision-maker status of the judiciary power, such initiative is left with the executive power according to the current regulation. Leaving with the practice intended as a judiciary measure at the hands of an executive body shall bring along the risk of arbitrary measures and abuse of such measures. As a result, there is room for possible violations of particularly those rights until the prosecutor steps in.

In summary, such authority which should be vested in the prosecutor's office as a part of the judiciary power which has an independent and impartial identity is given to the police who is a part of the executive power that holds the political power. As is definite in accordance with the decisions of the ECtHR, violation of the right to liberty and security and the right to life or prohibition of torture and inhuman or degrading treatment represents the largest share out of the total violations of Turkey. In light of the statistics of the ECtHR for the years between 1959 and 2014 in relation to the violations on the part of Turkey, it is seen that 994 out of 4,278 total violations are of those two rights mentioned above (ECtHR, 2015b). Moreover, the country-based statistics for the year 2014 indicate that Turkey was the country whose violations of the right to liberty and security accounted for the most, namely 45 times (ECtHR, 2015a). Such statistics point out that Turkey, which does not have a clean background in terms of violations of such rights, needs to act sensitively in this regard. Otherwise, it may lead up to the prevalence and systematization of the violations of right to liberty and security and the right to life or prohibition of torture and inhuman or degrading treatment; and unfortunately, the mentioned legal regulation bears such a risk.

The progress reports published by the EU in the previous years emphasize the necessity to enhance the control of the prosecutor over the law enforcement bodies. For example, 2012 and 2013 progress reports underline that prosecutors must enhance their capacities to effectively refer and manage the investigations carried out by the police and strictly control the proceedings carried out by the police (EC, 2012, p. 71; 2013, p. 45).

Another risk posed by such jurisdiction is that it eliminates the principle of separation of powers with the intervention by the executive power in the judiciary power. In the progress reports of the past years, the EU's highlighting its detections on Turkey's violations of the principle of separation of powers as 
an open subject of criticism (EC, 2012; 2013) sheds light on the fact that it is necessary for the countries and Turkey which want to join the Union to attach importance to such principle. In addition, the fact that Herman Van Rompuy, the previous President of the EU Council, emphasized the importance of Turkey's commitment to sustain the principle of separation of powers as a vital part of the Copenhagen political criteria and José Manuel Barroso, the previous President of the European Commission, emphasized that separation of powers is not only a fundamental principle of democracy but also a 'fundamental and vital' element of the EU negotiation process $(B B C, 2014)$ represent another indication that sheds light on the fact that it is necessary for Turkey, which conducts the negotiation process for the sake of EU accession, to remain committed to the principle. However, such regulation that bestows judicial powers and authorities upon the executive power also poses a severe threat against the principle of separation of powers.

Furthermore, following the fact that separation of powers is one of the essential elements of democracy, the jurisdiction under discussion also constitutes a threat to the development of democracy in Turkey. As is well known, in pluralistic democracy power is not collected under a single body but is used by three distinct bodies: legislation, executive and judiciary. No power can establish superiority over the other or breach its border. Therefore, these three powers must carefully and meticulously avoid interfering with each other's remit. However, entrusted with such an authority, the Turkish executive falls within the remit of judiciary hereby contravening the separation of powers. In a nutshell, looking the subject in question from a wider perspective, the threat aimed at the separation of powers primarily damages the development of democracy in Turkey.

The authority to detain as a judicial authority is, as a consequence, left under the initiative of the executive power, and in this context, it has almost turned into an executive power. A work that has a judiciary nature will from now on be conducted by the police as the officer of the executive power. This poses a dangerous situation in the way it causes unjust and arbitrary detentions. From this aspect, it will contradict with the Article 5 of the European Convention on Human Rights (ECHR) that protects individuals against arbitrary restriction of liberties and stipulates guarantees of such protection, and will open the door for possible violation decisions against Turkey in the eye of the ECtHR. In consideration of the fact that Turkey has been sentenced to large amounts of compensations by the ECtHR (Hüseyin Yıldırım v Turkey [2007]; Koçakv Turkey [2007]) due to unjust and arbitrary detentions of the police during the period in which the police had the power to detain prior to the criminal law reform made in 2005, it will be inevitable for Turkey to face similar sanctions and reactions. 
In conclusion, far from being a progressive step in the negotiations process, this legal regulation is considered to be a setback, which will more likely take Turkey to the years before 2005 with regard to the similar judgements of ECtHR.

\subsection{Intervention in social incidents}

Another power of the police within its jurisdiction is the authority to intervene in social incidents. The basic right that will be affected either positively or negatively by the police in terms of this power is primarily the freedom of assembly and the right to protest. The police have to guarantee the freedom of assembly and the right to protest of the individuals while maintaining public order. In addition, considering that such right taking place among the essentials of the libertarian democratic order is one of the means of collective execution of the freedom of expression, it is also associated with the subject right. Taking into consideration that it is frequently claimed that one of the moment when the police uses disproportionate force is the moment of intervention in social incidents (Firat, 2014, p. 774), it becomes evident that it is necessary to act sensitively in terms of the subject power.

The amendment made by the Law no. 6638 in Article 33 of the Law on Meetings and Demonstrations no. 2911 stipulates 6 months to 3 years of prison sentence for those who participate in assemblies or demonstrations carrying the emblems or signs of illegal organizations or communities or wearing clothing resembling uniforms that bear such signs or emblems and those who participate in assemblies or demonstrations carrying banners, posters, placards, pictures, signs and tools that are considered illegal by the laws or shouting slogans that are considered illegal or transmitting such slogans through voice recorders (Law no. 6638, Art. 8 (b)).

The relevant regulation has widened the scope of the criminal acts that require prison sentence as differently from the past. In this context, carrying such emblems and signs, wearing clothing like uniforms that bear such elements, carrying objects such as banners, posters and placards and shouting subject slogans are included as new acts of crime, and a legitimate basis was created for the intervention in such acts by the police. However, in accordance with the ECtHR decision, the police can intervene in social incidents subject to certain limitations and under certain conditions. Accordingly, another condition observed in execution by the Court, which refers to the conditions of 'stipulation by law', 'legitimate purpose', 'necessity in a democratic society' and 'proportionality', is whether such social incidents involve 'violence' or not. In this sense, ECtHR stipulates that no peaceful demonstration should be intervened unless it involves 
violence. Otherwise, the intervention in acts that do not involve violence is considered by the ECtHR as a violation of freedom of assembly and the right to protest, respectively.

The case of Oya Ataman v Turkey [2007], which regards a lawyer and at the same time a member of the administrative board of Istanbul Human Rights Association, who was exposed to police intervention through the use of pepper spray, arrested and also prevented from making the public statement in the demonstration held to protest F-type prisons, is an obvious example. In her application to ECtHR, the Court ruled that it is important for the public authorities to show tolerance towards peaceful gatherings that do not include violence and danger for public order and concluded that there was a violation of article 11 of ECHR, freedom of assembly and association (Ataman v Turkey [2007]).

Only grounding on the condition of legitimacy in general in terms of intervention in social incidents, Turkey does not have a clean background in the eye of the ECtHR also in terms of the freedom of assembly and the right to protest. This is because, in consideration of the decisions ruled by the ECtHR in relation to the violations of freedom of assembly committed by each member country of the Council of Europe between the years 1959-2014, it is seen that Turkey is at the top of the list (ECtHR, 2015b). Such a picture clearly shows that Turkey must act responsibly and sensitively in terms of the right at issue as well and take into account whether a demonstration involves violence or is peaceful as an important criterion.

However, just 'carrying the emblem of an organization', 'wearing clothing resembling a uniform that bears such elements' or 'shouting slogans' do not involve violence. In this sense, they do not require intervention by the police in the acts of people carrying out such actions. Nevertheless, this provision expressly authorizes the police to intervene with the demonstrators in such cases. Just based on the reasons mentioned above, the police will be able to intervene in completely peaceful demonstrations which do not involve any violence. This will then pose a serious obstacle in the way of freedom of expression and assembly and the right to protest.

Considering the progress reports, it is seen that intervention in social incidents has been one of the issues that EU criticizes most about Turkey. In consideration of the progress reports of the last few years, it is seen that the use of excessive force by the police against demonstrators in social incidents becomes prominent as a common criticism uttered by the EU. Additionally, in the 2013 and 2014 progress reports of the EU, it is yet again directed as a common criticism that 
Turkey's regulation on the freedom of assembly and the right to progress and intervention by the law enforcement officers in the social incidents and the implementation thereof is not in compliance with the European standards that observe peaceful conduct of demonstrations (EC, 2013, p. 6; 2014, p. 15). What is more, in the 2014 progress report, it is expressly underlined that the basic criterion to be followed when using force to disperse demonstrators must be the involvement of violence in demonstrations rather than the violation of the law (EC, 2014, p. 15). However, such a regulation enables intervening in the new acts included in the relevant law; and this explicitly shows that Turkey will face similar criticisms in the following years, as well.

Another special jurisdiction of the police in relation to its power to intervene in social incidents is related to the use of firearms. Whereas intervention in social incidents by using force is one of the sensitive moments where the individual and the Government come face to face (İşgören, 2011, p. 135), intervention in similar events by using firearms is not only the most effective method but also has the severest consequences (Ery1lmaz \& Bozlak, 2009, p. 242). This jurisdiction is directly related to people's right to life. As it is clear, the police will either strengthen or weaken the rights in question through its authority to intervene in the social incidents that address various fundamental rights of individuals.

The Law no. 6638 has widened the authority of the police to use firearms. In this context, in accordance with the amendment in Article 16 of the Police Duties and Authorities Law no. 2559; the police has been given the right to use firearms on persons who assault or try to assault the police or others, buildings, public buildings, business places, sanctuaries, schools, dormitories and vehicles, etc (Law no. 6638, Art. 4). The provision in question has expanded the circumstances in which the police use their weapons against individuals who attack police or others. Due to the fact that the police officers are claimed to be either perpetrators or the suspects of the recent human deaths in Turkey, the expansion of police power to use their weapons will increase the possibility of abuse of the power in question. Thus, the police should be vested with the authority to use weapons to a certain extent that will not cause abuse and arbitrariness (Çelik, 2015, pp. 259-261).

In consideration of the relevant ECtHR decisions, the police is authorized to use firearms only under certain and strict conditions. In this context, the police may only use firearms depending on the existence of conditions of 'selfdefense', 'being unable to contain the resistance using physical and material force', 'absolute necessity' and 'proportionality'. Interventions other than those 
mentioned are considered by the ECtHR as reasons of violation of the right to life. To give an example, the case of Ülüfer $v$ Turkey concerns a person who was shot dead by a police as he was trying to escape in handcuffs from the Court after a hearing in a trial against him for theft. His mother, as the applicant, sued against Turkey at ECtHR claiming that the police officer used lethal force against her son. After its evaluation, the ECtHR criticized the use of firearm against the escaper, who did not pose a clear threat for the others and concluded that the lethal force employed by the police officer cannot be deemed absolute necessity (Ülüfer v. Turkey [2012]).

Moreover, the fact that investigations of the police officers who violate the right to life or cause injuries cannot be conducted effectively and the police get away with their actions reveals that the possible perils of such jurisdiction may be more severe. Such detection is also included in the progress reports of the EU. The 2012 and 2013 progress reports openly criticize the absence of swift, comprehensive and effective investigations on human rights violations by the law enforcement officers and the fact that law enforcers continue to be sentenced to short-term imprisonment or their sentences are postponed (EC, 2012, pp. 19-20; 2013, p. 50). The progress reports also speak of the existence of cases where disproportionate use of firearms by the police results in fatalities. For example, one of the prominent issues criticized in the 2010, 2011 and 2012 progress reports of the EU was the use of disproportionate force including fatal injuries (by firearms) by the law enforcement officers (EC, 2010, p. 18; 2011, p. 22; 2012, p. 19). In the 2013 progress report, the EU itself expresses that the fatalities caused by the use of excessive force and firearms by the law enforcement officers in mostly peaceful protests across the country are alarming (EC, 2013, p. 64).

Finally, in consideration of the statistics of the ECtHR on the human rights violations between the years 1959 and 2014, Turkey ranks the second with 121 violations following Russia in the right to life category, in which 25 countries had no violations and most of the remaining countries made violations in a single-digit number (ECtHR, 2015b). Such a situation reveals the extent of the efforts that the country needs to make in order to assure the right to life, which is considered as the prerequisite of all rights and liberties. However, in the light of the ECtHR decisions and statistics and EU progress reports, expansion of the scope of the authority of the Turkish police to use firearms, who have a bad mark in terms of both use of disproportional force and human rights violations due to use of them, may cast a darker shadow on the current picture. 


\subsection{Search}

Another power of the police within its jurisdiction is the authority to search. The term search, which can, in the most general terms, mean "to reveal something that is hidden" (Özbek et al., 2011, p. 305), can stand for both a forensic search that is "the act of search conducted in the residence of a person, surrounding places, searching the person himself or through his belongings in order to capture a suspect that is hidden or obtain the evidence that is hidden in order to achieve the purpose of the criminal procedure" (Toroslu \& Feyzioğlu, 2008, p. 241). and a preventive search that is "the procedure to prevent a crime from being committed or a danger from occurring and to protect the constitutional rights and liberties" (Doğan, 2011, p. 158). Such jurisdiction includes intervention in civil liberties, particularly the right to privacy and immunity of domicile, physical integrity and the freedom of travel.

The Law no. 6638 grants more extensive authorities to the police when searching people and their vehicles. In accordance with such powers, the extent of the places to be searched by the police is also widened. The police has been given the authority to conduct a search upon the written order of their superior or his verbal order in emergencies in accordance with the amendment made with the subject law in the Article 4/A 'Stopping and ID Check' of the Police Duties and Authorities Law no. 2559. In this sense, the police can search the person they have stopped, his belongings and the parts of his vehicle that are not visible from the outside upon the written order of the chief of the police force to be appointed by the local authority or, in case of emergencies, his verbal order to be confirmed in writing later on in the event of sufficient suspicion that the person has a weapon on him or in his car or an object that poses danger. The decision of the chief of the police force is submitted to the approval of the commissioned judge within 24 hours (Law no. 6638, Art. 1).

The first element that stands out in the regulation is the authority to search given to the police through the local authority for 24 hours, which was previously given to the police upon the written order of the local authority, provided that such authority was predicated upon the decision of the judge or the prosecutor and limited to the conditions where the public prosecutor could not be reached and delays were undesirable. While not to authorize police with the power to conduct a search ex officio beforehand was considered as an element of assurance that prevented arbitrary searches (Şafak \& Şafak, 2005, p. 253), such element of assurance has been ruled out with such regulation. Moreover, this authority can also be practiced upon the verbal order of the chief of the police force without the need to obtain his order in writing. Such situation which bypasses the ruling 
assured in Article 20 of the Turkish Constitution in relation to search and rules out the condition of written order is alarming in the way it causes arbitrary practices until the moment the judicial power steps in, and therefore, results in human rights violations. The regulation gives a wide scope of initiative and discretionary power to the police. The police will be able to search persons, their belongings and vehicles without needing any ruling and a written order.

The second element that stands out in the subject regulation is that the police, who previously did not require a person to get undressed or open the parts of his vehicle which are not visible from the outside, is now authorized to search a person and his belongings in addition to the parts of his vehicle which are not visible from the outside. In this sense, the scope of intervention by the police in the private life has been widened within the frame of the authority to search. The police will be able to conduct a detailed search in the wider scope of private life in which they will intervene thanks to the authority at issue.

Another element that stands out in the regulation is the condition that is required to conduct a search on the person stopped by the police or his vehicle is the sufficient suspicion that the person has a weapon or another object that poses a threat. However, especially the phrase "another object that poses a threat" addresses a rather wide category which includes various objects that people frequently carry or have on their belongings or carry in their vehicles. Even the existence of this reason only is enough to result in arbitrary practices.

Even though ECtHR considers it as an important assurance factor that searches are conducted upon a search warrant issued by a judge, it does not consider having a search warrant as a requisite under all circumstances. In this case, it does not rule that a search not predicated upon a judge's ruling automatically constitutes an unnecessary intervention in the private life. The Court accords the discretionary power to governments in this regard and essentially monitors the efficiency of the measures and assurances that will render it possible to control the unnecessariness and unjustness of intervention in private life (Eryllmaz, 2003, p. 303). In this context, the ECtHR justifies the intervention of the police in accordance with such power provided that it is 'justifiable' in accordance with the conditions stipulated in the Article 8 on the respect for private life of the ECHR, it follows at least one of the 'legitimate aims' defined in the second paragraph of the same article and it is 'necessary in a democratic society' in order to materialize such purpose. The expression 'justifiable' in the intrinsic jurisprudence of the Court speaks of the necessity that the measure in question should both be based upon domestic law and comply with the 'rule of law'. When considering whether the 'rule of law' principle is observed or not, the 
Court looks into whether or not a discretionary power that may cause arbitrary intervention is given to the authority.

As a matter of fact, the ECtHR acts more sensitively in cases where authorities can issue search warrants and conduct searches without a judiciary instruction according to the national laws. This is because the Court believes in the necessity of protecting individuals against arbitrary interventions in the principle of respect for private life by authorities and of clearly defining the boundaries of this authority (Miailhe v France [1993]; Camenzind v Switzerland [1997]; Varga $v$ Romania [2008]). In the case of Camenzind $v$ Switzerland [1997], for instance, the Court reminded that the contracting states can require to take measures such as searching for gathering evidence about particular crimes. In addition, although the Court accepted that the states have discretionary power regarding this issue, at the same time it stressed that in the cases where the related public authorities have the power to search without a judiciary instruction, the states must make searches with meticulous care (Camenzind $v$ Switzerland [1997]).

In consideration of the violations of the principle of respect for private life by the British police, who have the authority to search people and their vehicles in accordance with a written or verbal order to be obtained from their superiors without the need for a judge's order, it will be seen that rather than the order in question the assurances mentioned above are considered as basis. In the case of Gillan and Quinton v the United Kingdom [2010], for instance, the ECtHR considers the wide scope of the discretionary power mostly bestowed on the police officers for conducting searches as an important element to put emphasis on. According to the Court, vesting extensive authority with the police poses a serious risk of arbitrariness. As a result, when the Court detects that sufficient legal assurance is not provided against the abuse of such authority, it may rule that the intervention by reason of such authority is 'unjustifiable' and decide that Article 8 of the ECHR which is 'respect for private and family life' is violated (Gillan and Quinton v the United Kingdom [2010]).

The judgement of the ECtHR given in relation the act of British police above sheds light on another significant point. The relevant decision presents a counterargument against the claim that the package under discussion is in tune with the European standards since some EU Member States already had similar legal regulations. This can be illustrated by the above case about the United Kingdom, which significantly increased the scope of stop and search under its counterterrorism law. In the case of Gillan and Quinton v the United Kingdom [2010], which concerns a protestor and a journalist who were stopped and searched on their way to a demonstration held near an arms fair, the Court drew the attention 
to the risks that wide discretion given to the police may pose. According to the Court, "there is a clear risk of arbitrariness in the grant of such a broad discretion to the police officer" (Gillan and Quinton v the United Kingdom [2010]).

In its progress reports issued in relation to Turkey, the EU does not provide a clear evaluation peculiar to the police's authority to search in question. However, by principle, the Union is against granting public institutions an extensive discretionary power that may result in the limitation of civil rights and liberties. On the contrary, it also believes in the necessity to limit the discretionary power of such authorities in order to prevent abuse of such power and arbitrary practices. For example, in the 2002 progress report, in accordance with the amendment in the Police Duties and Authorities Law through the third reform package approved within the scope of the EU harmonization packages, it was welcomed to take certain measures against abuse of power by limiting the discretionary power of the police (EC, 2002, pp. 29-30). On the contrary, in the 2014 progress report, in relation to the freedom of assembly, the EU reported that although the Constitution gives citizens the right to assemble and make demonstrations without prior permission, the related legislation gives a wide scope of discretionary power to the authorities which in turn limits the freedom in practice to a great extent (EC, 2014, p. 53).

In the light of those determinations, the police's authority to search given within the scope mentioned above does not have clear boundaries and there is no sufficient assurance to prevent arbitrary treatment and abuse of such power. However, in consequence of arbitrary treatment, which is rendered possible by such an authority, fundamental rights of the individuals, such as the right to privacy and the right to physical integrity, can be infringed (Çelik, 2015, p. 244). As a result, by reason of the arbitrary practices and abuse of power, which are possible due to the extensive discretionary power granted to the police, it is anticipated that Turkey will face cases of violation in the eye of the ECtHR. 


\section{Conclusion}

The Europeanization-oriented reform process of Turkey that started fast with gaining the candidate status and continued to be intense for a certain time was then followed by a period of regression in recent years. Deviation from the Europeanization goal is due to the reason of national origin as well as that of foreign origin. Particular national matters in the country, for instance, led the ruling party to adopt certain laws that prioritized security and curtailed freedoms, which constitute a contradiction against European standards. The Law no. 6638, which is the subject of this study, is a case in point. It is certain that the package under discussion will yield adverse outcomes for both Turkey itself and EUTurkey relations.

To start with the consequences for Turkey, the package specifically poses a challenge for Turkey's democracy in the sense of plurality, since it makes the power centralized in the monopoly of the ruling party and engenders repressive and authoritarian practices in the country. It precludes the realization of a diversity of views and identities in a country where various opinions exist and where groups are free to express themselves within a political system. Suppressing some opinions in a society decreases the level of plurality and thus damages the democracy of that country. The package, which will likely cause breach of human rights including the freedom of expression and freedom of assembly, both of which are prerequisites of plurality, in fact poses a risk for Turkey's democracy.

The package yields certain consequences with respect to the impression it leaves on EU-Turkey relations, as well. It is clear that the package, which imperils democracy by hampering the reflection of plurality and disrupting the balance of freedom-security against the favor of freedom, and opens a road to human rights violations by granting the police discretionary power leaves a negative mark in the negotiation process between the EU and Turkey. Like the other laws adopted during the second phase of Europeanization process in Turkey, the package is clearly incompatible with the European standards.

One can argue that the package is in line with the European standards since some of the EU Member States already had similar laws which, for example, give the police the right to detain a person up to 24 hours as in France, 36 hours as in the United Kingdom, and 48 hours as in Germany; the right to search people and 
their vehicles on his own motion as in Germany and United Kingdom; and the right to intervene the protestors hiding their faces as in Germany. However, what is really binding for Turkey is not the applications in the Member States but the judgements of ECtHR and considerations of the EU. Moreover, as highlighted by Emma Sinclair-Webb (2015), a researcher at Human Rights Watch, past experiences of the police and its current record concerning arbitrary treatment puts Turkey in a category different from Member States. ${ }^{3}$ This necessity even becomes clearer when we compare the number of the ECtHR decisions on Turkey and those of Member States in question. Even the number of the infringement decisions of ECtHR on Turkey before the Turkish police was given such authorities is much larger than the number of the infringement decisions of ECtHR on the aforementioned countries, which already had those powers. This leads us to the conclusion that each state must be evaluated based on its own peculiar conditions, such as its political structure and other structural differences in its security systems.

To put it more explicitly, Germany, which is inspired by the Government for the package under discussion and which could be considered as another example of 'pick-and-choose' approach adopted by the Government in the post-2007 period, differs from Turkey in many respects including its political structure. As stressed by the chief of Germany's Police Union, Rainer Wend (2015), in his interview on the package under discussion, Germany is very strict in the implementation of the principle of separation of powers. It has also a more strict control mechanism over the police practices. The police organization is headed by high-level officers independent from the Government. What is more, German has certain nuances in its relavant legislation. For instance, any suspects or their vehicles in Germany can be searched by the police only if there is concrete suspicion for a crime. Also, any protestors in Germany who cover their faces are punishable only if they are inclined to use violence (Martin Scheinin in Geerdinck, 2015).

Furthermore, the threats and risks regarding discretionary power that the package under discussion may pose and the fact that the package was not meeting key European standards were even noted by the EU itself. Granting broad discretionary powers to the police in relation to the power to search, detain and use arms without judicial or independent parlimentary oversight was the major critique for the package made by the EU. In its latest progress report on Turkey, the EU, in addition, regarded the adoption of this package as a "significant

3 For the full commentary of Emma Sinclair-Webb about the package, see SinclairWebb, 2015. 
backsliding" in the Europeanization process, specifically in the areas of freedom of expression and freedom of assembly (EC, 2015, p. 62).

In conclusion, it is clear that the package, which will result in various violations of right in practice and which contradicts with the 'human rights' and 'democracy' values of the Union, shall have negative reflections on the relations between Turkey and the EU. The package will continue engender the loss of the gains in terms of democracy and human rights that Turkey achieved in the first phase of Europeanization process. Thus, the adoption of such a package is considered to be another manifestation of the setback in the Europeanization process of Turkey. The package was also a significant manifestation of the fact that the Government maintains consolidating its enhanced power position in the political arena and increasing its control over the judiciary that started with the post-2007 period.

To reverse the current situation and put Turkey again on the path to Europeanization, both EU and Turkey should take responsibility. On the one hand, to revitalize the Europeanization process, EU should motivate and encourage Turkey so that Turkey gains momentum in the process and adopts new political reforms which will promote democracy and human rights. On the other hand, Turkey should take advantage of any opportunities that will develop an intimacy with the EU. The EU's goodwill and desire shown at EU leaders summit on Syrian refugee crisis on 29 November 2015 to open new negotiation chapters is regarded as a unique opportunity that Turkey should utilize. In this sense, opening of the new chapter 17 'Economic and Monetary Policy' on 14 December 2015 as the first concrete step after the summit in question and other chapters such as; 'Judiciary and Fundamental Rights', and 'Justice, Freedom and Security', which are expected to open in the following months, for instance, offer a significant chance for Turkey to reactivate the relations with the EU and start a fresh democratic reform process.

Vahap Atilla Oğuşgil is assistant professor at İnönü University in Turkey. He received his $\mathrm{PhD}$ in the field of European Union from the İstanbul University in Turkey. His research interests include European Union and European Union-Turkey relations. His publications are specifically concerned with European Union-Turkey relations within the context of human rights and national human rights institutions including ombudsman and equality bodies. His work has appeared in many national and international journals such, as Turkish Journal of Police Studies, Review of International Law and Politics, International Journal of Social Inquiry and Eastern Journal of European Studies, among others. 


\section{References}

Alpan, B. \& Diez, T. (2012), 'Europe and domestic struggles: demarcating political frontiers in Turkey.' Paper presented at the 9th Convention of the Central and Eastern European International Studies Association (CEEISA), Cracow, 20 -22 September 2012.

Ataman v Turkey [2007], ECtHR 74552/01, 05.12.2006.

$B B C$ (2014), 'EU Presses Turkish PM Erdoğan over Democratic Reforms', $B B C, 21$ January 2014. Retrieved from http://www.bbc.com/news/world-europe-25824512 [accessed Dec 2015]

Bowling, B.; Phillips, C.; Campbell, A. \& Docking, M. (2004), Policing and Human Rights, Eliminating Discrimination, Xenophobia, Intolerance and the Abuse of Power from Police Work, Geneva: United Nations Research Institute for Social Development.

Camenzind v Switzerland [1997], ECtHR 21353/93, 16.12.1997.

Cavalieri, P. (2005), 'Genişletilmiş Bir İnsan Hakları Kuramı İçin' [For an expanded theory of human rights], translated into Turkish by S. Nilüfer, Birikim, no. 195, pp. $37-40$.

Çelik, A. (2015), ‘Özgürlük ve Güvenlik Bağlamında İç Güvenlik Paketinde Yer Alan Bazı Maddelerin Değerlendirilmesi’ [The evaluation of some articles of domestic security package in the aspect of freedom and security], Uyuşmazlık Mahkemesi Dergisi, vol. 8, no. 5, pp. 235-263.

Centel, N. (1994), 'Koruma Tedbirlerinde Gelişmeler' [Improvements in protection measures], Hukuk Araştırmaları, vol. 8, nos. 1-3, pp. 69-99.

Coşkun, V. (2013), 'Constitutional amendments under the Justice and Development Party rule,' Insight Turkey, vol. 15, no. 4, pp. 95-113.

Crawshaw, R. (1997), 'Introduction to the seminar on human rights and the police: human rights, the rule of law and policing,' in Human Rights and the Police: Seminar Proceedings, Strasbourg: Council of Europe, pp. 11-20.

Doğan, D. Ç. (2011), 'Ceza Muhakemesinde Adli Arama' [Judicial search in penal procedure], Türkiye Barolar Birliği Dergisi, no. 92, pp. 157-180.

EC (2002), 2002 Regular Report on Turkey's Progress towards Accession, Brussels, SEC(2002) 1412, 09.10.2002.

(2010), Turkey 2010 Progress Report, Commission Staff Working Document, Brussels, SEC(2010) 1327, 09.11.2010.

(2011), Turkey 2011 Progress Report, Commission Staff Working Document, Brussels, SEC(2011) 1201 final, 12.10.2011.

(2012), Turkey 2012 Progress Report, Commission Staff Working Document, Brussels, SWD(2012) 336 final, 10.10.2012. 
- (2013), Turkey 2013 Progress Report, Commission Staff Working Document, Brussels, SWD(2013) 417 final, 16.10.2013.

- (2014), Turkey 2014 Progress Report, Commission Staff Working Document, Brussels, SWD(2014) 307 final, 08.10.2014.

(2015), Turkey 2015 Progress Report, Commission Staff Working Document, Brussels, SWD(2015) 216 final, 10.11.2015.

ECtHR (2015a), The ECtHR in Facts and Figures: 2014. Retrieved from http://www. echr.coe.int/Documents/Facts_Figures_2014_ENG.pdf [accessed Dec 2015] (2015b), Violations by Article and by State: 1959-2014. Retrieved from http://www. echr.coe.int/Documents/Stats_violation_1959_2014_ENG.pdf [accessed Dec 2015]

Eralp, A. \& Torun, Z. (2015), 'Perceptions and Europeanization in Turkey before the EU candidacy: an overview of history,' in A. Tekin \& A. Güney (eds.) The Europeanization of Turkey: Polity and Politics, Abingdon: Routledge, pp. 14-30.

Eryılmaz, M. B. (2003), Türk ve Ingiliz Hukukunda ve Uygulamasında Durdurma ve Arama, [Stop and search in Turkish and English law and practice], Ankara: Seçkin Publishing.

Eryılmaz, M. B. \& Bozlak, A. (2009), 'Hukukumuzda Zor ve Silah Kullanma Yetkisi' [Right to use force and arms in our law], Türkiye Barolar Birliği Dergisi, no. 83, pp. 223-277.

EU Network of Independent Experts on Fundamental Rights (2003), The Balance Between Freedom and Security in the Response by the European Union and its Member States to the Terrorist Threats. Retrieved from http://ec.europa.eu/justice/ fundamental-rights/files/cfr_cdf_themcomment1_en.pdf [accessed Dec 2015]

Fırat, E. (2014), 'Toplanma Özgürlüğü ve Sınırları, Toplumsal Olaylara Müdahelenin AİHS'in 3. Maddesi Kapsamında Değerlendirilmesi' [Freedom of assembly and its limits, the evaluation of the intervention against social incidents within the scope of the $3^{\text {rd }}$ Article of ECHR], Türkiye Adalet Akademisi Dergisi, vol. 5, no. 19, pp. 745-791.

Geerdinck, F. (2015), Turkey Copy-Pastes European Laws. Retrieved from https:// www.beaconreader.com/frederike-geerdink/turkey-copy-pastes-european-laws [accessed Dec 2015]

Gillan and Quinton $v$ the United Kingdom [2010], ECtHR 4158/05, 12.01.2010.

Grigoradis, I. N. (2009), Trials of Europeanization, New York: Palgrave MacMillan.

Güven, S. (2006), Meşruiyet Kaynağı Olarak Insan Hakları: Helsinki Süreci [Human rights as the source of legitimacy: the Helsinki process], Unpublished MA Thesis, University of Bilgi, İstanbul.

Hafner-Burton, E. M.; Tsutsui, K. \& Meyer, J. W. (2008), 'International human rights law and the politics of legitimation: repressive states and human rights states,' International Sociology, vol. 23, no. 1, pp. 115-141. http://dx.doi. org/10.1177/0268580907084388 
Hale, W. (2011), "Human rights and Turkey's EU accession process: internal and external dynamics, 2005-10," South European Society and Politics, vol. 16, no. 2(June), pp. 323-333. http://dx.doi.org/10.1080/13608746.2011.577953

Hüseyin Ylldırım v Turkey [2007], ECtHR 2778/02, 03.05.2007.

İşgören, A. (2011), Toplantı ve Gösteri Yürüyüşleri [Meetings and demonstrations], Ankara: Seçkin Publishing.

Kaliber, A. (2014), 'Europeanization in Turkey: in search of a new paradigm of modernization,' Journal of Balkan and Near Eastern Studies, vol. 16, no. 1, pp. 30-46. http://dx.doi.org/10.1080/19448953.2013.864182

Karaosmanoğlu, F. (2012), Insan Hakları [Human rights], Ankara: Seçkin Publishing. Koçak v Turkey [2007], ECtHR 32581/96, 03.05.2007.

Law no. 6638 (2015), Law no. 6638 Amending the Law on Police Duties and Authorities, Law on Gendermerie Organization, Duties and Authorities and Certain Laws, Resmi Gazete [Official Gazette], no. 29316, 4 April 2015.

Miailhe v France [1993], ECtHR 12661/87, 29.11.1993.

Ministry of Foreign Affairs (2007), Political Reforms in Turkey, Ankara: Dumat Ofset Press.

Öniş, Z. (2008), 'Turkey-EU relations: beyond the current stalemate,' Insight Turkey, vol. 10 , no. 4 , pp. $35-50$.

(2010), “Contesting for Turkey's political centre: domestic politics, identity conflicts and the controversy over EU membership,' Journal of Contemporary European Studies, vol. 18, no. 3, pp. 361-376. http://dx.doi.org/10.1080/147828 04.2010 .507919

Özbek, V. Ö.; Kanbur, N.; Doğan, K.; Bacaksız, P. \& Tepe, İ. (2011), Ceza Muhakemesi Hukuku [Penal procedure law], Ankara: Seçkin Publishing.

Özbudun, E. (2004), Türk Anayasa Hukuku [Turkish Constitutional Law], Ankara: Yetkin Publishing.

Özdemir, H. \& Demirkanoğlu, Y. (2014), “Helsinki Zirvesi’nden Günümüze Türkiye'nin Avrupa Birliği’ne Üyelik Sürecinin Ülkedeki Kadın Politikalarına Etkileri" [The effect of membership process of Turkey to European Union since Helsinki Summit until today on women policies in the country], Uludağ Journal of Economy and Society, vol. 33, no. 2, pp. 103-126.

Saatçioğlu, B. (2013), 'Turkey-EU relations from the 1960s to 2012: a critical overview,' in B. Akçay \& B. Y1lmaz (eds.) Turkey's Accession to the European Union: Political and Economic Challenges, Maryland: Lexington Books.

(2014), “AKP's 'Europeanization' in civilianization, rule of law and fundamental freedoms: the primacy of domestic politics,' Journal of Balkan and Near Eastern Studies, vol. 16, no. 1, pp. 86-101. http://dx.doi.org/10.108 0/19448953.2013.864185 
Şafak, A. \& Şafak, A. Ş. (2005), Güvenlik Kuvvetleri ve Polis Mevzuatı [Security forces and police legislation], Ankara: Liberte.

Sinclair-Webb, E. (2015), 'Is Turkey just copying the EU in increasing police powers?,' Hürriyet Daily News, 14 February 2015. Retrieved from http://www. hurriyetdailynews.com/is-turkey-just-copying-the-eu-in-increasing-policepowers-.aspx?pageID $=238 \& n I D=78328 \&$ NewsCatID $=396$ [accessed Dec 2015]

Toroslu, N. \& Feyzioğlu M. (2008), Ceza Muhakemesi Hukuku [Penal procedure law], Ankara: Savaş Publishing.

Ülüfer v. Turkey [2012], ECtHR 23038/07, 05.06.2012.

Varga v Romania [2008], ECtHR 73957/01, 01.04.2008.

Wend, R. (2015), “Almanya Polis Sendikası Başkanı: Türkiye'de Yapılanın AB’yle Almanya'yla Alakası Yok" [Chief of Germany's Police Union: The regulation has nothing to do with the EU and Germany], Diken, 19 February 2015. Retrieved from http://www.diken.com.tr/almanya-polis-sendikasi-baskani-turkiyedekidurumun-abyle-almanyayla-alakasi-yok/ [accessed Dec 2015]

Yenisey, F. (1995), Insan Hakları Açısından Arama, Elkoyma, Yakalama ve Ifade Alma [Search, seizure, arrest and statement taking with regards to human rights], Ankara: Ankara University, The Faculty of Political Sciences Human Rights Center.

Yılmaz, G. \& Soyaltın, D. (2014), “Zooming into the 'domestic' in Europeanization: promotion of fight against corruption and minority rights in Turkey," Journal of Balkan and Near Eastern Studies, vol. 16, no. 1, pp. 11-29. http://dx.doi.org/10.1 080/19448953.2013.864181

Zeldin, W. (2015), Turkey: Counterterrorism and Justice, Washington, DC: Global Legal Research Center \& The Law Library of Congress. 